DOI https://doi.org/10.30525/978-9934-26-073-5-2-79

\title{
СОВРЕМЕННЫЕ ТЕНДЕНЦИИ В МЕТОДИКЕ ПРЕПОДАВАНИЯ ИНОСТРАННЫХ ЯЗЫКОВ, ОБУЧЕНИЕ ИНОСТРАННОМУ ЯЗЫКУ С ИСПОЛЬЗОВАНИЕМ МОБИЛЬНЫХ УСТРОЙСТВ
}

\author{
Ясинская Т. А. \\ старший преподаватель кафедры романо-германских языков и \\ методики их преподавания \\ факультета лингвистики и перевода \\ Международного гуманитарного университета
}

Гриценко В. И.

преподаватель кафедры германских и восточных языков и перевода факультета лингвистики и перевода Международного гуманитарного университета г. Одесса, Украина

Стремительное развитие компьютерных технологий и их внедрение в систему образования требует также переосмысления всей системы образования в соответствии с новейшими достижениями и изменившимися требованиями.

Сам процесс обучения переносится в пространство мобильных технологий, следовательно количество приложений для обучения и образовательных проектов для мобильных устройств неуклонно растет. Особенно это стало заметно в последние полтора года, когда, в связи с пандемией, весь мир был вынужден перейти на систему удаленного обучения, что привело к пересмотру всей системы образования в сторону использования мобильных технологий.

Термин мобильное обучение (м-обучение) или mobile learning (m-learning) обозначает использование мобильных и портативных устройств, например, мобильных телефонов, ноутбуков и планшетных персональных компьютеров, в преподавании и обучении [1].

В современной методике преподавания иностранных языков уже существует ряд работ, касающихся мобильного обучения - С.В. Титова [6], К.В. Капранчикова [2], Ю.В. Трошина и Н.О. Вербицкая [7] уже рассматривали условия внедрения мобильного обучения в образовательный процесс. 
Внедрение мобильного обучения в образовательный процесс стало результатом того, что компьютеры и интернет стали частью повседневной жизни, что привело к развитию мобильных технологий в сфере образования. Основным преимуществом такого обучения стало обучение в любое время и в любом месте. Помимо работы в аудитории, мобильное обучение может широко использоваться и для самостоятельной работы студента.

В книге Handbook of mobile learning [8] авторы делают акцент на том, что мобильное обучение может происходить в любое удобное для студента время, причём студент может сам сам определять подход, удовлетворяющий его цели; он также может использовать устройство для поиска необходимой информации. Окружающая среда может являться частью обучения - например, сканирование кодов для получения дополнительной информации. При всем разнообразии мобильных приложений, их можно разделить на несколько подгрупп - интерактивные курсы (English Conversation, Duolingo, Lingualeo, Anki Droid), языковые социальные сети (HiNative, EdModo), мультимедийные приложения (BBC Learning English).

А. Кукульска-Хьюм [3] отмечает, что в данном случае понятие мобильность относится не только к технологиям, но и к студенту и контенту. Мобильность - возможность преодоления пространственных и временных границ.

Основными преимуществами мобильного обучения являются его персонализация и неформальность. Это, своего рода способ мотивации студентов к дальнейшему обучению, так как в этом случае повышается ответственность студента, его отношение к самообразованию, к личностному и профессиональному росту. При использовании мобильного обучения, могут быть задействованы основные современные методы обучения - личностно-ориентированное, программированное, мультимедийное, интерактивное и т.д.

Но, несмотря на все преимущества мобильного обучения, отечественные и зарубежные ученые отмечают его незрелость с точки зрения педагогической проработки и должного применения [5; 7]. Мобильные приложения уже активно используются преподавателями, но, при этом нет системы, определяющей критерии выбора того или иного приложения. Также большое значение имеет наличие в вузе открытой ресурсной среды и соответствующей технической базы.

Таким образом, использование мобильных технологий при обучении иностранным языкам, несомненно, имеют ряд преимуществ. Следова- 
тельно, необходима разработка новых методик преподавания, анализ возможностей и контента существующих мобильных приложений, а также создание новых, направленных на решение той или иной задачи.

\section{Литература:}

1. Герасименко Т.Л., Гулая Т.М., Грубин И.В., Жидкова О.Н., Зенина Л.В., Лобанова Е.И., Романова С.А. Лингвострановедческий аспект обучения иностранным языкам с применением современных интернет технологий: коллективная монография. М., МЭСИ. 2013. 119 с.

2. Капранчикова К.В. Мобильные технологии в обучении иностранному языку студентов нелингвистических направлений подготовки // Язык и культура. 2014. № 1 (25). С. 84-94.

3. Кукульска-Хьюм А. Мобильное обучение. Аналитическая записка. Институт ЮНЕСКО по информационным технологиям в образовании. C. 1-2. URL: http://iite.unesco.org/pics/publications/ru/files/ 3214679.pdf (дата обращения: 17.04.2021)

4. Левин М. Как технологии изменят образование: пять главных трендов. http://www.forbes.ru/tehno/budushchee/82871 (дата обращения: 18.04.2021)

5. Самохина Н.В. Использование мобильных технологий при обучении английскому языку: развитие традиций и поиск новых методических моделей // Фундаментальные исследования. 2014. № 6-3. C. 591-595.

6. Титова С.В. Условия успешной интеграции мобильных устройств в учебный процесс [Электронный ресурс] //Современные информационные технологии и ИТ-образование. 2012. № 8. С. 262-269.

7. Трошина Ю.В., Вербицкая Н.О. Мобильное обучение иностранному языку: понятие, функции, модели [Электронный ресурс] // Современные проблемы науки и образования. 2015 . № 3. URL: http://bit.ly/2KIXxdi (дата обращения: 20.04.2021).

8. Zane L. Berge, Lin Y. Muilenbyrg. (Ed.) Handbook of mobile learning. - UK: Routledge, 2013 